mir, aumentar investimentos dos particulares ou lograr melhor situação na balança de pagamentos, incentivando as exportações, por exemplo;

9) o sistema tributário deve possibilitar o aumento automático de suas receitas, sem prejudicar o desenvolvimento, sempre que for necessários ou houver um crescimento econômico da nação. Deve ter suficiente elasticidade;

e) o sistema tributário deveria viabilizar a variação das bases coletáveis segundo os objetivos políticos que se tenha em mira. Devem ser escolhidas as matérias tributáveis dentre aquelas que melhor se coadunam com os fins visados.

Observadas estas condições, podemos concluir que o sistema tributário torna-se uma verdadeira variável, durante o processo de desenvolvimento do país, adequando-se, não só através de suas linhas mestras, mas também mediante suas normas de execução, não apenas aos objetivos que se buscam, mas também à escolha das matérias imponíveis.

\title{
A conversão da dívida externa latino-americana em projetos ambientais: uma resposta da "novíssima ordem econômica internacional" aos problemas do endividamento e do meio ambiente.
}

\section{Isabella Soares Micali}

Master of Law em Direito Internacional Econômico pela

London School of Economics; Doutora em Direito

Internacional Econômico na Universidade de Paris I.

\section{Maristela Basso}

Professora de Direito Internacional da Universidade Federal do Rio Grande do Sul, da PUC/RS e da Unisinos; Doutoranda em Direito Internacional na

Universidade de São Paulo; Membro Fundadora e Diretora da

Associação Brasileira de Estudos da Integração-ABEI.

\section{SUMÁRIO}

I. Considerações iniciais; II. O mecanismo de conversão da dívida externa em projetos ambientais: a) as partes envolvidas; b) as etapas da negociação; c) o objeto da conversão; d) os instrumentos jurídicos das conversões; III. As experiências latino-americanas de conversão da dívida externa em projetos ambientais: a) Bolívia; b) Equador; c) Costa Rica; IV. Condições e limites das conversões da dívida externa em projetos ambientais: a) quanto ao país devedor; b) quanto às organizações internacionais não governamentais de proteção ao meio ambiente; $c$ ) quanto às organizaçōes locais não governamentais de proteção ao meio ambiente; d) quanto aos bancos credores; V. Sugestões de um programa para o Brasil; VI. Conclusões: Notas: Bibliografia

\section{Considerações iniciais}

O mês de agosto de 1992 marcará o décimo aniversário da crise do endividamento internacional dos países do Terceiro Mundo em geral, e da América Latina em particular. Desde o telefonema do então Ministro da Economia do México, J. Herzog, declarando a moratória de pagamentos externos à comunidade financeira internacional, muito e, ao mesmo tempo, pouco tem sido feito para resolver uma crise cuja duração é relevadora de um mal crônico. Os anos oitenta se tornaram para o desenvolvimento da América Latina a tristemente famosa "década perdida".

Paralelamente, nesta mesma década, a comunidade internacional despertou para os problemas do mau uso dos recursos naturais, e o meio ambiente passou a ser considerado como o "patrimônio comum da hu- manidade", cuja proteção se faz cada dia mais urgente e imperativa.

O Terceiro Mundo, nesta virada, apareceu como o alvo de inúmeras críticas e renovadas esperanças na luta de hoje e de amanhã para a proteção do que é percebido como um bem comum que transcende as fronteiras nacionais e os conceitos clássicos da soberania das nações.

Verdade ou não, a proteção do meio ambiente tornou-se, aparentemente, uma preocupação dos países desenvolvidos que diante dos estragos por eles infringidos à sua própria natureza, começaram uma cruzada para que os países do Terceiro Mundo implementassem novas políticas ambientais a fim de proteger o que fora encarado como sendo res omnium.

Desta forma, a Amazônia, por exemplo, tornou-se, na linguagem popular e vulgar, o 
"pulmão do mundo". E comum lermos aqui e acolá que os países em via de desenvolv mento enfrentam problemas de sub-desenvolvimento humano que colocam as preocupações ambientais em segundo plano.

No entanto, o grande desafio da décad de noventa para os países dos Continentes Latino-americano, Africano e Asiático ser o de demonstrar, caso seja ainda necessário que a proteção do meio ambiente não uma preocupação de segunda ordem, ou um luxo reservado às elites, mas, sim, um problema primordial e intrinsecamente ligado ao desenvolvimento econômico e humano.

Os problemas da dívida externa e da proteção do meio ambiente não estão, prima facia, intrinsecamente ligados.

Porém, a conversão da dívida externa em projetos ambientais (debt-for-nature swaps) realizou este tour de force econômico e jurí dico. A paternidade da idéia pertence ao $\mathrm{Dr}$. Thomas Lovejoy que, já em 1984, sugeriu redução da dívida a fim de liberar recurso capazes de enfrentar os problemas ambientais dos países devedores.

Geralmente, numa transação de conversão da dívida externa em projetos ambientais, uma organização internacional não governamental de proteção ao meio ambiente $(\mathrm{OING})^{1}$ adquire, no mercado secundário da divida ${ }^{2}$ o crédito detido por uma banco comercial internacional referente a uma divida contraída por um país do Terceiro Mundo. A OING compra estes títulos com um deságio em relação ao seu valor de face, ou pode também recebê-los como doação por parte do banco credor. Em posse deste títulos a OING aceita, então, que seja cancelada a dívida constante dos mesmos em troca do compromisso assumido pelo país devedor de implementar projetos de proteção ambiental ou consagrar mais fundos conservação dos recursos naturais. Com esta finalidade, o país devedor pode fornecer de uma só vez o equivalente em moed nacional, com ou sem deságio, ou emitir bônus cujos rendimentos serão utilizados no projeto ambiental. Visando a conclusão desta transação a OING recorre a uma or ganização local não governamental de pro- teção ao meio ambiente (OLNG), a qual desempenhará um papel de coordenação e promoção do projeto ambiental no país devedor.

As conversões ambientais são operações complexas e sofisticadas que reunem partes com estatutos jurídicos diversos, e cujos instrumentos são de difícil negociação.

Até a presente data, uma dúzia de projetos desta natureza foram concluídos em diversos países em desenvolvimento, cancelando, aproximadamente, 100 milhões de dólares do débito internacional; montante modesto quando se leva em consideração a vultosa dívida externa destes mesmos países (1,4 trilhões de dólares).

Neste trabalho, apresentaremos uma análise do mecanismo de conversão da dívida externa em projetos ambientais; descrevemos as experiências concluídas no Continente Latino-americano; faremos uma avaliação das condições limites de tal transação e tentaremos propor algumas linhas de sugestão para que tais conversões sejam levadas a efeito no Brasil.

II. O mecanismo de conversão da dívida externa em projetos ambientais

a) As partes envolvidas

O mecanismo das conversões da dívida em projetos ambientais faz intervir em um ou vários instrumentos quatro partes principais: as autoridades administrativas e políticas do país devedor; as organizações internacional e local não governamentais de proteção ao meio ambiente; e o banco comercial internacional, ou outra entidade credora.

As autoridades administrativas e políticas do país devedor: para que seja concluído um projeto de conversão de dívida em programas ambientais é necessário, antes de mais nada, que exista no país uma conscientização pública acerca dos problemas pertinentes aos recursos naturais e que se implemente uma política de proteção e conservação do patrimônio ambiental nacional. Conforme analisaremos mais adiante, o país que conheceu o maior êxito quanto aos progra- mas de conversões ambientais foi a Costa Rica, justamente porque ali o poder público tem demonstrado uma preocupação de longa data no que concerne ao meio ambiente.

As entidades administrativas que podem intervir são o Banco Central e o Ministério da Economia, ou das Finanças, os quais são tradicionalmente responsáveis pelas negociações e conclusões dos acordos de dívida externa, e possivelmente o Ministério da Agricultura, ou mesmo uma Secretaria ou Agência dos Recursos Naturais ou Ambientais, caso exista. Os interesses destes distintos entes são diferentes e até mesmo opostos: o Banco Central, ou Ministério da Economia, no momento da emissão dos bônus para conversão dos títulos da dívida externa, tentarão conseguir o deságio máxi mo para limitar a emissão de moeda nacional, enquanto que o Ministério da Agricultura, e/ou dos Recursos Naturais, tentarão obter um deságio mínimo para conseguir o maior financiamento possivel para projetos de conservação e proteção ambientais.

Os programas de conversões ambientais serão grandemente facilitados se o Banco Central tiver adotado e implementado uma regulamentação acerca das conversões da dívida externa em projetos de investimentos (Debt-for-equity swaps) ${ }^{3}$.

Cumpre também aos Parlamentos dos países latino-americanos exercer a devida pressão política sobre os seus dirigentes para que programas consistentes e eficientes de desenvolvimento e proteção ambiental a longo prazo sejam adotados, implementados e executados. Da mesma forma lhes incumbe promover campanhas educacionais visando a conscientização das populações locais no que concerne ao meio ambiente e ao seu uso ecológico.

As organizações internacionais não governa mentais de proteção ao meio ambiente (OING): as OINGs mais ativas na área de interesse são: a) The Nature Conservancy (TNC), sediada em Arlington, Virgínia; b) World Wildlife Fund (W.W.F.), sediada em Washington D.C.; c) Conservation International (C.I.), também sediada em Washington D.C..
Recentemente foi criada uma OING da qual podem participar somente outras OINGs, a Debt-for-Development Coalition, com o objetivo de promover conversões da dívida em projetos educacionais, ambientais e industriais.

Estas organizações recebem fundos privados ou públicos com os quais adquirem os títulos da dívida no mercado secundário ou os recebem diretamente como doação por parte dos credores.

As OINGs revelam as preocupações ambientais das populações dos países nos quais estão sediadas, independentemente das políticas seguidas pelas autoridades destes mesmos países. Entendemos não prosperarem as afirmações de ques estas organizações seriam parciais e instrumentos de "políticas imperialistas". É verdade que elas não podem se medir com os governos soberanos dos países devedores, e o correto uso de sua assistência, financeira e técnica, depende somente do modo em que é negociado o acordo de conversão da dívida em projetos ambientais. Daí porque, cumpre aos Estados devedores que pretendem implementar programas desta natureza utilizar os recursos propostos da maneira que parecer mais adequada às necessidades das comunidades locais.

As organizações locais não governamentais de proteção ao meio ambiente (OLNG): as organizações locais são elementos imprescindiveis para o êxito e o bom funcionamento de todo projeto de conversão da dívida em programa ambiental. As OLNGs cabe o importantíssimo papel de servir de "elo" entre as OINGs e as autoridades locais. No caso da Costa Rica, por exemplo, a Fundación de Parques Nacionales concluíu com as autoridades administrativas costa-riquenses um acordo interno relativo a programas de conversões ambientais, e a seguir firmou com várias OINGs acordos visando receber os fundos doados. Do que se conclui ser fundamental que o relacionamento entre a OLNG e as autoridades locais, por um lado, e as OINGs, por outro, seja sólido e baseado numa confiança a longo prazo. 
Os bancos credores: estes devem estar dispostos a livrar-se dos créditos que detém, vendendo-os no mercado secundário, ou doando-os às OINGs. Desde 1987, os bancos comerciais internacionais, sobretudo norte-americanos, mais envolvidos na América-Latina, começaram a constituir reservas para perdas no que respeita aos seus créditos concluídos com países daquela região. Muitos deles estão dispostos a vender tais títulos e até mesmo doá-los, porém encontram dificuldades, haja vista a falta de incentivos fiscais e contábeis.

Além dos bancos, outras entidades credoras poderiam intervir neste processo de conversão. Os governos credores até agora desempenharam um papel modesto nesta área, levando-se em consideração que, como as OINGs, alguns governos adquiriram, como se sabe, títulos no mercado secundário da dívida internacional, mas ainda não demonstraram interesse em abrir mão dos seus próprios créditos a favor de projetos de conversão ambiental. Os organismos públicos de assistência ao desenvolvimento dos países credores poderiam, da mesma forma, desempenhar um papel de relevo nesta área.

Os bancos multilaterais de desenvolvimento também poderiam cumprir um papel central nos programas de conversão da dívida em projetos ambientais: poderiam, como os bancos credores, aceitar que seus créditos fossem pagos em moeda nacional em troca de progressos na política ambiental dos países devedores, ou poderiam fornecer novos créditos, ou garantias para que tais projetos fossem concluídos ${ }^{4}$.

\section{b) As etapas da negociaşão}

As negociações envolvidas nas conversões de dívida em projetos ambientais são extremamente complexas e de longa duração. Dois ou três anos são no mínimo necessários entre a concepção e a realização de um projeto desta envergadura.

Inicialmente, o governo devedor com as OLNGs e OINGs determinam se um projeto de conversão ambiental é desejável e viável. A seguir os detalhes da conversão (de- ságio, taxa de juros dos bônus, prazo do mesmos etc.) devem ser estabelecidos, geral mente pelo Banco Central do país devedor Após a OING interessada deverá levantar os fundos necessários junto às fontes privadas ou públicas visando a aquisição dos título da dívida no mercado secundário. A organização deverá, em particular, identificar um banco credor disposto a concluir tal cessão e analisar o mercado secundário. Para que a OING obtenha a melhor taxa de deságio possível, faz-se mister que exista um mercado secundário relativamente amplo para o país devedor em questão. Isso é de particular importância para os países latinoamericanos que concluíram sua dívida externa essencialmente com os bancos comerciais internacionais. As conversões ambientais tornar-se-ão mais fáceis para os países da região frente à existência de um amplo mercado secundário da dívida latino-americana.

A OING, então, poderá transferir os títulos adquiridos e convertê-los em bônus emitidos a favor da OLNG pelo banco central do país devedor, e cujos rendimentos serão utilizados para financiar os projetos ambientais.

\section{c) O objeto da conversão da dívida em} projetos ambientais

Os programas de conversão incluem vários tipos de ações, dentre as quais podemos destacar: aquisição de terrenos para a constituição de parques naturais; projetos de reflorestamento; despoluição de rios e mares reabilitação e conservação de espécies em via de extinção; projetos de pesquisas e de educação; programas agrícolas, ecológicos alternativos; proteção do habitat e costumes tradicionais das populações indígenas, evitando a penetração de atividades agroindustriais que provoquem a deportação das mesmas etc.

Quando da negociação, o governo devedor precisará definir quais são as suas prioridades ambientais, em colaboração com as OINGs e as OLNGs, determinando, por exemplo, listas ou categorias de projetos prioritários ou definindo programas específicos. d) Os instrumentos jurídicos das conversões da dívida em projetos ambientais

Do ponto de vista formal, existem duas modalidades de conversões da dívida externa em projetos ambientais: a) modalidade "caso a caso"; b) modalidade "institucionalizada".

A modalidade caso a caso cobre a hipótese em que cada negociação inclui todas as partes acima referidas. Esta foi a modalidade encontrada nas primeiras experiências ainda seguida na maioria dos casos. Porém, a tendência é a sua substituição por umá esquema "institucional", o qual economizará tempo e ganhará em eficiência. No esquema "caso a caso" de conversão, cada transação será submetida ao cumprimento de todas as etapas, desde a definição do projeto pelas autoridades administrativas, até emissão de bônus, passando pela conclusão do contrato entre a OING e a OLNG.

A conversão "caso a caso" inclui vários instrumentos jurídicos. Trata-se, por um lado, de uma série de contratos: o contrato entre o governo e a OING; o contrato entre a OING e a OLNG; o contrato administrativo entre as autoridades locais e os vário entes nacionais (OLNGs, fundo fiduciário, banco administrador etc.); e, de outro lado, de legislações ambientais (regulamentações administrativas e/ou leis parlamentares) dos países devedores que são objeto dos contratos acima mencionados, como acon teceu nas negociações bolivianas analisada mais adiante.

A modalidade institucionalizada apareceu recentemente no caso da Costa Rica, quando tornou-se claro que a estratégi "caso a caso" não proporcionaria a conclusão de um número mais expressivo de conversões ambientais. Neste enfoque, as autoridades administrativas locais, o Banco Central e os Ministérios competentes, podem adotar um quadro geral que institucionalize as transações de conversão ambiental. Este quadro geral terá por meta descrever as competências e respectivas responsabilidades das partes intervenientes, fixar os pormenores financeiros das conversões, legali- zar o estatuto dos fundos fiduciários, determinar as regras de procedimento que serão seguidas em cada negociação específica e definir as linhas gerais dos projetos a serem financiados. Além do mais, poderão ser designados administradores (bancos nacionais, p.ex.) e comissões mistas que terão por missão definir mais detalhadamente os projetos a serem financiados, bem como seguir o desenvolvimento das transações a longo prazo. Dentro deste quadro institucional terá lugar cada negociação específica entre as OINGs e as OLNGs que serão aprovadas pelas autoridades administrativas locais.

Cumpre-nos salientar que ambas as modalidades devem ser incluídas e previstas nos instrumentos de reescalonamento da dívida externa ${ }^{5}$ e, como já foi dito, serão facilitadas pela existência de um esquema de conversão da dívida em projetos de investimento.

III. As experiências latino-americanas de conversão da dívida externa

em projetos ambientais

Já foram realizadas experiências de conversão da dívida externa em projetos ambientais em três países latino-americanos: Bolívia, Equador e Costa Rica. Outras experiências foram também concluídas nos Continentes Africano e Asiático. Entretanto, limitar-nos-emos às transações realizadas no Continente Latino-Americano, sem atentarmos àquelas levadas a efeito nas Filipinas, Madagascar e Zambia, as quais, da mesma forma, apresentam características significantes.

Além dos três países latino-americanos acima citados, outros projetos da mesma natureza estão em estudo para a Argentina o Brasil, a República Dominicana, a Jamaica, o México, o Panamá, o Peru e a Venezuela.

\section{a) Bolívia}

A experiência boliviana é a mais antiga Alvez a mais rica de ensinamentos para 0 futuro. 
No dia 13 de julho de 1987 foi assinado ntre a Conservation International (C.I.), organização não governamental cuja estratégia principal são os problemas de destruição florestal, sediada em Washington, e o Governo boliviano, um acordo para a preservação da Reserva Biológica do Beni.

A região do Beni, como se sabe, cobre uma enorme superfície, situada na parte nordeste do país e conhecida pela sua extraordinária riqueza em fauna e flora. A importância desta Reserva repousa no fato de que ela mantém oito mil espécies de plantas, quinhentas espécies de pássaros e dezoito espécies de animais em via de extinção. A área do Beni é também a pátria dos índios nômades Chimane.

Por intermédio de seu agente Citicorp In vestment Bank, sediado em Nova Iorque, a C.I. adquiriu de um banco suíço o equivalente a 650.000 dólares em títulos da dívida boliviana no mercado secundário da dívida por uma quantia de 100.000 dólares. Os recursos foram fornecidos à C.I. através de uma doação da Frank Weeden Foundation, instituição de caridade situada na Califórnia que faz doações exclusivamente para causas ambientais. Em contrapartida do cancelamento de sua dívida externa, o Governo boliviano deveria:

a) promover a conservação e proteção das reservas totalizando 4 milhões de acres;

b) criar um novo e reforçado estatuto jurídico para a Região do Beni;

c) elaborar um plano de administração e uso ecológico da terra, do qual participassem as populações locais.

A C.I., no referido acordo, designou uma instituição local, Liga de Defesa del Medio Ambiente, com a finalidade de que esta atuasse como seu representante na Bolívia Por outro lado, a C.I. se dispunha a fornecer por cinco anos uma assistência científica, técnica, financeira e administrativa ao Governo boliviano com a devida aprovação dos Ministérios da Agricultura e do Planejamento. Paralelamente, a C.I. se comprometeu a fornecer relatórios anuais aos aludidos Ministérios, assim como ao Ministério das Relações Exteriores.
A luz do acordo, um fundo de administração equivalente a 250.000 dólares em moeda local deveria ser constituído e depositado numa conta operacional que financiaria os projetos de proteção da região do Beni. O Governo boliviano forneceria $40 \%$ desta quantia (100.000 dólares) e a Agency for International Development contribuiri com o restante (150.000 dólares), tão logo fosse depositada a participação boliviana. Diante de graves dificuldades econômicas, - Governo boliviano honrou seu compromisso quase dois anos depois do fechamento do acordo, em 10 de abril de 1989, paralizando assim todos os projetos.

Vê-se, por conseguinte, que este programa não possuía somente um suporte políti co, como demonstrou a ativa participação de líderes políticos bolivianos no mesmo, mas possuía também um suporte econômico de 250 mil dólares em fundos para conduzir, administrar e proteger a reserva biosfera. Além do mais, residentes locais, durante o "Congresso das Associações Cívicas", votaram dar 7\% das rendas fiscais obtidas das atividades florestais para sustentar a Reserva.

Sabe-se também que o Governo boliviano não implementou uma legislação de proteção jurídica máxima exigida pelo acordo, mas sim uma lei cuja meta era definir princípios gerais de proteção ambiental no país.

Este acordo foi alvo de severas críticas causou inúmeros transtornos na sociedade boliviana, frente às acusações proferidas em direção da C.I. segundo as quais ela estaria adquirindo a Reserva do Beni e ditando a política ambiental da Bolívia, violando, conseqüentemente, a soberania nacional.

Estes incidentes revelam o quanto é necessário que a organização local encarregada da implementação do projeto desempenhe um forte papel quanto à correção da informação divulgada, bem como se empenhe plenamente na coordenação administrativa, financeira e política do projeto de conversão.

Há que se observar que a não existência de um programa de conversão da dívida em investimentos (dedt-equity swaps) na Bo- lívia tornou mais dificil a implementação de um programa de conversão ambiental. O que revela a importância da instituição prévia de um programa geral de conversões no país devedor para que sejam facilitadas as conversões da dívida externa em projetos ambientais.

Esta primeira experiência revela as dificuldades de se introduzirem cláusulas pertinentes à resolução de controvérsias (como arbitragem, escolha da lei, escolha do forum) nos acordos de conversão de dívida em, projetos ambientais, deixando as partes envolvidas sem recursos jurídicos frente a possíveis litígios.

Não resta dúvida que as dificuldades en contradas foram inúmeras, todavia, há que se salientar a importância desta transação pioneira que abriu novas portas e perspectivas para que outros idênticos, ainda que aprimorados, fossem realizados em outro países latino-americanos, africanos e asiáticos. O suporte local e o envolvimento $d$ população boliviana, em espírito e na prática, foram fatores extremamente importantes para garantir o sucesso do programa.

Cumpre-nos registrar, também, que um segundo projeto de conversão da mesm natureza está em andamento, com a possibilidade de uma doação por parte de um banco credor da Bolívia.

\section{b) Equador}

Frente a um processo de degradação da riqueza biológica de seu meio ambiente de suas graves dificuldades financeiras externas, o Equador lançou, em 1987, um vasto e ambicioso programa de conversões am bientais fundamentado nas propostas de Roque Sevilla, ex-presidente da Fundació Natura, principal organização de proteção ambiental do Equador ${ }^{6}$.

Em outubro de 1987 o Banco Central do Equador emitiu uma Resolução n. JM-259FN para implementar um programa de conversão da dívida externa equatoriana em projetos ambientais. De acordo com esta Resolução, a dívida convertida deveria fazer parte do acordo de reescalonamento do dé- bito do Equador firmado com os bancos credores em 15 de agosto de 1986, e para tanto o Banco Central emitiria a favor da Fundación Natura bônus não negociáveis num valor máximo de dez milhões de dólares. A referida Fundação disporia de um prazo máximo de cinco anos para apresentar os títulos da dívida para a conversão e seria responsável pela documentação contratual e jurídica da transação.

Três projetos desta natureza foram realizados no Equador

Em 14 de dezembro de 1987 foi concluído entre a World Wildlife Fund (W.W.F.) organização ambiental sediada em Washington, e a Fundación Natura um acordo segundo o qual a W.W.F. adquiriria um milhão em títulos da dívida externa equatoriana por $35 \%$ do seu valor de face 354.000 dólares) no mercado secundário da dívida. $O$ Banco Central do Equador, por sua vez, emitiria bônus num montante de $100 \%$ do valor de face da dívida convertida em moeda local à taxa oficial de câmbio. Os juros provenientes dos bônus serviriam como recursos para que a Fundación Natura financiasse programas de proteção, administração e aquisição de reservas naturais, assim como de treinamento de pessoal. Os bônus venceriam num prazo de nove anos, constituindo uma dotação em capital a favor da Fundação.

Todos os projetos selecionados em comum acordo entre a Fundación Natura e a W.W.F. haveriam de ser compatíveis com as metas governamentais, o que afastaria possíveis discussões acerca da violação da soberania daquele país.

A segunda conversão foi concluída entre The Nature Conservancy (T.N.C.), sediada na Virgínia, Estados Unidos, e a Fundación Natura, em 22 de março de 1989, pouco antes da terceira que se realizou entre a W.W.F. e a referida organização equatoriana, em 04 de abril do mesmo ano. A luz destes acordos a T.N.C. adquiria 3,6 milhõ es de dólares e a W.W.F. 5,4 milhões em títulos da dívida externa equatoriana, títulos esses detidos pela Morgan Guaranty Trust Company e a American Express Bank, por um 
valor de $12 \%$ do seu valor de face, preço muito abaixo do vigente no mercado secundário da dívida. Os títulos resgatados seriam convertidos a $100 \%$ do seu valor de face à taxa de câmbio oficial em bônus de nove anos.

Visando a seleção dos projetos, seria instituída uma "comissão mista" composta por representantes da Fundación Natura, outras organizações ambientais locais interessadas e agências administrativas equatorianas, comissão esta que atuaria em colaboração com as W.W.F. e a T.N.C.

Observa-se que no caso equatoriano não foram encontradas dificuldades em relação ao problema da soberania nacional, pois a organização ambiental local assumiu um fortíssimo papel na negociação e administração dos projetos, assim como incluíu as autoridades administrativas do país, tanto na fase preliminar (com a adoção da Resolução do Banco Central), como na fase de implementação do projeto propriamente dito.

O Equador, no futuro, pretende estender esta experiência para projetos de mais amplo porte (conversão da dívida em projetos de desenvolvimento - debt-for-development swaps), incluindo programas sociais, culturais e educacionais, num montante de 50 milhões de dólares.

\section{c) Costa Rica}

Os programas desenvolvidos na Costa Rica obtiveram um grande êxito, considerando-se a tradicional abertura e conscientização deste país quanto aos problemas ambientais em geral.

Em agosto de 1987 o Banco Central da Costa Rica criou um fundo fiduciário, "Fundo Nacional de Conservação dos Recursos Naturais" (F.N.C.R.N.), o qual receberia os títulos convertidos sob forma de bônus emitidos em moeda local. Tal Fundo, por sua vez, proveria financiamentos para o planejamento, administração e proteção dos parques nacionais, aquisição de propriedades para projetos de conservação, imple170 mentação de programas educacionais e de controle de reflorestamento.

A Fundación de Parques Nacionales (F.P.N) foi designada como a organização ambiental encarregada de concluir os acordos. paralelamente, a Bancoop (Banco Cooperativo da Costa Rica) seria o administrador do referido fundo fiduciário.

Em outubro de 1987 foi concluído um acordo entre o Ministério dos Recursos Naturais, o Banco Central e a F.P.N. a fim de determinar os respectivos papéis e responsabilidades na administração das conversões em projetos ambientais. Este acordo previa que o Governo costariquense trocaria até 5,4 milhões de dólares em títulos da dívida externa emitindo bônus nominados em moeda local a $75 \%$ do valor de face e à taxa de câmbio do mercado paralelo. Tais bônus não negociáveis possuiriam um prazo de cinco anos e nove meses e seus juros seriam utilizados pela F.P.N. para financiar atividades de conservação de recursos naturais no país.

O Ministério dos Recursos Naturais e o Banco Central estavam capacitados para verificar e controlar a utilização dos recursos financeiros pelo fundo fiduciário e a administração dos mesmos pelo Bancoop.

O acordo de 1987 não menciona as organizações de proteção ambiental estrangeiras que seriam envolvidas no processo de conversão. $\mathrm{O}$ aludido acordo refere-se somente às doações que poderiam ser feitas por pessoas ou instituições interessadas na conservação dos recursos naturais.

Em março de 1988 foi assinado um acordo entre a W.W.F. e a F.P.N., que foi avalizado pelo Banco Central e o Ministério dos Recursos Naturais, segundo o qual a W.W.F. adquiriria três milhões de dólares (sobre os 5,4 milhões autorizados), a $17 \%$ do valor de face, em títulos da dívida externa da Costa Rica, convertidos em bônus cujos rendimentos seriam utilizados pela F.P.N. em projetos ambientais prioritários (cinco parques nacionais e reservas naturais).

Os restantes 2,4 milhões de dólares foram doados por várias organizações estran- geiras de proteção ao meio ambiente, nos mesmos termos, permitindo assim que num único projeto de conversão participassem várias instituições.

Em maio de 1988 o Banco Central aumentou a quota máxima de conversões para 11 milhões de dólares. Em janeiro de 1989 foi concluído a segunda conversão, a T.N.C. e outras instituições adquiriram 5.6 milhões de dólares por um valor de 784.000 dólares do "American Express Bank". O Banco Central da Costa Rica converteu os títulos da dívida a $30 \%$ de seu valor de face e emitiu o equivalente de 1,7 milhões de dólares em bônus.

Ainda em janeiro de 1989, foi assinado o primeiro acordo de conversão ambienta entre o governo de um país industrializado e um governo devedor. Os Países Baixos adquiriram 33 milhões de dólares em títulos da dívida da Costa Rica por uma quantia de $15 \%$ do valor de face $(5$ milhóes de dólares) no mercado secundário. O Banco Central da Costa Rica, por sua vez, converteu estes títulos em bônus a $30 \%$ do valor de face dos títulos cancelados (10 milhões de dólares), com um prazo de quatro anos e um rendimento de $15 \%$ ao ano.

A Costa Rica e os Países Baixos estabeleceram um fundo e uma "comissão mista" de trabalho.

Em abril de 1989 foi assinada uma outra conversão do mesmo tipo, na qual o Governo sueco adquiriu 28 milhões da dívida da Costa Rica por 3,5 milhões de dólares, os quais foram convertidos a $70 \%$ de seu valor de face em bônus cujos rendimentos foram atribuídos ao F.P.N. para implementação de um projeto relativo ao "Parque Naciona Guanacaste".

A experiência da Costa Rica apresent um particular interesse posto que o pais "institucionalizou" o programa de conversões ambientais, ao invés de aplicar um enfoque "caso a caso", como ocorrera até então.

Em fevereiro de 1989 o Banco Centra adotou novas e extensivas regras no tocant às conversões de dívida externa em projetos ambientais, educacionais e industriais, instituindo assim um programa mais amplo de conversão para projetos de desenvolvimento - debt-for-development swaps (Resolução $\mathrm{n}$. 4338-89).

A partir de então, os novos bônus emitidos não seriam negociáveis e seriam nominados em dólares a $80 \%$ do valor de face dos títulos convertidos, com uma taxa de juros de 3\%; ou em colones (moeda local) a $100 \%$ do valor de face com uma taxa de juros de $8 \%$. Esta disposição tem como meta resolver parcialmente as ansiedades das instituições estrangeiras de proteção ambiental relativamente ao problema crônico existente nos países latino-americanos de erosão monetária, haja vista que os problemas inflacionários podem, como se sabe, comprometer os futuros recursos disponíveis a favor da organização ambiental local e, conseqüentemente, a favor dos projetos financiados com os rendimentos dos bônus.

De acordo com esta Resolução o Banco Central da Costa Rica assegura o monitoramento das conversões e fiscaliza a boa $e$ correta utilização dos fundos pelo banco administrador.

Tal Resolução abre novas e encorajadoras perspectivas para o futuro das conversões de dívidas externas em projetos de desenvolvimento, em geral, e de proteção ambiental, em particular, no país em tela.

IV. condições e limites das conversões da dívida externa em projetos ambientais

Conforme vistos, as conversões da dívida externa em projetos ambientais são mecanismos complexos que requerem a existência de várias condições para a sua implementação. As conversões são instrumentos jurídicos flexíveis que devem atender as necessidades e as aspirações de todas as partes que nela intervem. Da mesma forma, estão submetidas aos limites inerentes ao funcionamento dos seus protagonistas.

a) Quanto ao país devedor

Vimos anteriormente, que a vontade política do país devedor para implementar 
programas ambientais é um elemento fundamental.

Muitas vozes se elevaram contra os projetos de conversão da dívida em programas ambientais como sendo violações inadmissíveis da soberania nacional. $\mathrm{Na}$ experiência boliviana, o projeto de conversão foi vítima de boatos errôneos, segundo os quais uma organização estrangeira estava adquirindo o patrimônio nacional e, por conseguinte, ditando a política ambiental boliviana. $O$ próprio governo boliviano mostrou-se incapaz de explicar à comunidade nacional o verdadeiro conteúdo das conversões de dívida em projetos ambientais. Entendemos, porém, que tais acusações carecem de sólida fundamentação jurídica, tendo em vista o importante e vital papel que desempenham as autoridades nacionais numa conversão de tal natureza - da iniciativa de tal programa até a implementação final.

$\mathrm{O}$ debt-for-nature swap não é um instrumento de "ditadura ambiental estrangeira": o país e a sua população são os principais beneficiários da transação. Não somente o país devedor vê uma parte de sua dívida cancelada, ainda que de forma modesta, mas consegue deste modo financiamentos concretos para projetos de maior significação e que tradicionalmente não recebem os merecidos incentivos. Por outro lado, a OING não adquire nada no país devedor e nem se apropria do patrimônio natural ou industrial local.

Cabe, portanto, ao país devedor negociar da maneira mais vantajosa possível e fazer uso mais adequado dos recursos disponíveis e propostos pelas OINGs.

Outro limite que se destaca é o relativo às pressões inflacionárias que se exercem sobre a economia do país devedor sempre que este recorre de uma maneira ou de outra (capital ou bônus) à criação monetária. E bem verdade que o potencial inflacionário existe para todo tipo de conversão, no entanto esta pressão é praticamente mínima para as conversões ambientais. Quando os bônus são emitidos, o país evita proceder a um pagamento pontual, como é o caso dos debt-for-equity swaps, os juros dos bônus são 172
Da mesma forma, quando da conversão dos títulos em bônus, a OING espera obter o menor deságio possível, a fim de rentabilizar ao máximo a transação. Por outro lado, a OING pretende que a taxa de câmbio seja a mais próxima possível da taxa de câmbio paralela e que os juros provenientes dos bônus sejam reajustados para protegêlos da erosão monetária.

Finalmente, vale lembrar que a OING atribuirá muita importância às relações de confiança e recíproca colaboração mantida com a OLGN, assim como ao sólido compromisso assumido pelo país devedor de que as políticas ambientais acordadas serão efetivamente implementadas.

c). Quanto às organizafóes locais não governamentais de protę̧ão ao meio ambiente

A organização local não governamental é um elo imprescindível entre a OING e as autoridades administrativas do país devedor. Daí porque ela deve ser uma organização forte que goze de um certo prestígio que tenha capacidade de exercer pressão e influência. A experiência boliviana mostrou os riscos inerentes a uma OLNG deficiente. A fortaleza da organização local será uma garantia para afastar acusações de violação à soberania nacional.

Além de manter boas relações com OING, a OLNG deve possuir uma grande experiência no campo da proteção do meio ambiente, relacionar-se em modo cooperativo com as populações locais afim de despertar uma melhor consciência ecológica, bem como assegurar a continuidade de sua ação a longo prazo.

\section{d) Quanto aos bancos credores}

Os bancos comerciais internacionais precisam encontrar um estímulo para abrir mão dos títulos das dívidas externas que detém. No que diz respeito à venda pelos bancos destes títulos no mercado secundário, o incentivo econômico é claro: muitos deles já constituíram importantes reservas para perdas e estão dispostos a vender seus créditos ainda que com um considerável deságio. O problema é muito diferente quando se trata de doações. O tratamento fiscal e contábil que foi até agora reservado às doações de bancos norte-americanos mais envolvidos nas economias latino-americanas, não têm propiciado estas transferências de títulos a favor das OINGs.

A Resolução da Receita Federal NorteAmericana (Internal Revenue Service - IRS), Revenue Ruling 87-124, adotada em 1987, dispõe que um banco americano pode beneficiar-se de vantagens fiscais se doar os seus créditos a uma organização de caridade, ou sem finalidade de lucros, num montante equivalente ao valor de mercado de tal crédito.

Muitos bancos, porém, não estão dispostos a realizarem doações, pois as vantagens fiscais seriam limitadas ao valor dos títulos cotados no mercado secundário e não ao valor de face. Assim sendo, os bancos norte-americanos preferem vender tais títulos com deságio e beneficiar-se de vantagens fiscais por perdas do que enfrentar uma perda maior caso doem seus créditos. Cabe, portanto, aos países desenvolvidos, sede dos bancos credores, implementarem legislações que facilitem e promovam estas doações.

\section{Sugestões de um programa para o} Brasil

A política seguida pelo Brasil até agora mostrou-se veementemente oposta a qualquer tipo de conversão da dívida em projetos ambientais, o que fica evidenciado pelas declarações do ex-Presidente José Sarney no sentido de que tais conversões constituíriam "uma intolerável interferência na política ambiental soberana do país".

Sem dúvida, um passo jurídico importante foi dado com a aprovação da nova Constituição Federal de 1988, cujo art. 225, preceitua que o "Governo tem a missão de proteger e defender o meio ambiente para as gerações futuras". No entanto, a política ambiental, em particular a florestal, seguida pelo Brasil não deixa de ser assustadora.

O Brasil implementou políticas de assentamento na região amazônica, assim como da divida do país em questão, a fim de sível. 
incentivou, através do INCRA (Instituto Nacional de Colonização e Reforma Agrária), a agropecuária e criação de pastos neste local.

Tal política é criticável não só a nível ecológico, como também econômico; os pastos, como é sabido, provocam o fenômeno de exaustão rápida dos solos tornandoos em poucos anos impróprios para a agricultura e totalmente improdutivos.

O Brasil destrói a cada ano 2.323 hectares de florestas. Por outro lado, o ex-Secretário do Ambiente, José Lutzenberger, revelou que a floresta amazônica produz dez vezes mais alimentos (frutas, caça e peixes) que o produzido pelos pastos numa mesma superfície. Diz-nos também este especialista que um acre de pantanal produz mais proteínas que um acre de gado. O Brasil importa $2 / 3$ de borracha que utiliza quando poderia conseguí-los a um custo menor se fosse produzida na floresta que destrói. Os recursos em madeira não são nem mesmo utilizados, e das árvores queimadas não se aproveita nem o carvão. o Brasil promove uma política de destruição de recursos naturais valiosos, ao invés de aplicá-los num programa econômico racional e viável.

No entanto, a partir de 1990 o Brasil suspendeu os programas de incentivos fiscais e de subsídios para desflorestação ${ }^{9}$ e dobrou o orçamento do IBAMA (Instituto Brasileiro do Meio Ambiente e Recursos Naturais Renováveis), o qual aplicou uma política severa de controle das queimadas não autorizadas (9 milhões de dólares de multas em 1990). A desflorestação diminuiu de $50 \%$ neste período. O ex-Secretário Lutzenberger se opôs vigorosamente a vários projetos, dentre os quais: a construção de uma auto-estrada, de centrais hidroelétricas e de mineração de ferro.

A falta de recursos é um problema crucial e nevrálgico de toda a política ambiental brasileira, e a falta de coragem política torna as pressões dos grandes interesses econômicos um empecilho para programas ambientais de maior envergadura.

As reformas promovidas não são suficientemente aprofundadas para, de maneira 174 eficiente, protegerem a floresta amazônica da destruição.

Esta não é uma fatalidade contra a qua carecemos de recursos. O Brasil poderia, por exemplo, constituir grandes reservas ambientais nas quais, em partes delas, nenhuma atividade humana seria tolerada, e reservar o restante da floresta para usos econômicos alternativos. Porém, insistimos, lucrativos (cultivo da seringueira, industrialização de óleos vegetais e nozes, safra de frutas, criação de peixes em represas, corte seletivo e racional da madeira, ao invés das queimadas anárquicas).

Entretanto, o custo de financiamento para a manutenção e proteção dos recursos naturais está muito acima do que o Brasil poderia dispor. Os debt-for-nature swaps seriam um meio de suprir estas deficiências financeiras.

Os problemas ambientais do Brasil, todavia, não se limitam às florestas e pantanais. Outras regiões brasileiras conhecem problemas agudos de poluição. O Brasil poderia, graças ao uso inteligente de conversões da sua dívida externa em projetos ambien tais, financiar programas de despoluição de rios e de mares, assim como de reabilitação do solo, da fauna e da flora.

Há que se considerar também que o problema indígena no Brasil continua grave. Estas populações sofrem o ataque sistemático de industriais e fazendeiros, e a violação de seus direitos como cidadãos brasileiro tornou-se um problema de desrespeito aos direitos humanos. Urge, assim, que as autoridades brasileiras tomem as necessárias me didas a fim de proteger o habitat das suas populações indígenas. $O$ problema enconrado na Bolívia com os índios Chimanes revela o quanto é necessário, na definição dos projetos de conversão da dívida em programas ambientais, que sejam levados em conta os legítimos interesses dos índios.

Recentemente registrou-se uma mudança na posição brasileira no que se refere às conversões da dívida em projetos ambientais. Em julho de 1991, o Presidente Fernando Collor de Mello aceitou a idéia de que anualmente sejam convertidos 100 milhões de dólares da dívida externa brasileira em projetos ambientais, e se declarou disposto a estudar a possibilidade de implementar um programa experimental de proteção ao meio ambiente. Assim, o Banco Central do Brasil adotou uma Resolução e uma Circular a fim de delimitar um quadro funcional para as operações de conversão da dívida externa brasileira em projetos ambientais

A Resolução n. 1.840, de 16 de julho de 1991, institui um "Plano de Conversão da Dívida Externa para Fins Ambientais", com o objetivo de permitir o acolhimento, por parte de instituições ou fundos sem fins lucrativos, mediante doações de recursos destinados à preservação do meio ambien te $^{10}$. Qualquer instrumento da dívida externa poderá ser utilizado na transação (art. 2 da Resolução). O Banco Central do Brasil liberará recursos, ao par, em benefício da entidade brasileira donatária, os quais serão destinados exclusivamente à aquisição de títulos públicos federais, cujos rendimento serão utilizados nos referidos projetos am bientais (arts. 3 a 5 da Resolução)

A Circular n. 1.988, adotada no mesmo dia, "Divulga decisão da Diretoria relacionada com o Plano de Conversão da Dívid Externa para Fins Ambientais"11. Esta Circular fixa o limite máximo de conversões (100 milhões de dólares), e descreve o procedimento a ser seguido nas conversões $d$ dívida externa brasileira em projetos ambientais.

A política de austeridade fiscal e monetária, assim como as dificuldades encontradas nos programas de debt-for-equity swaps, não foram empecilhos para que o Brasi aprovasse recentemente, no dia 12 de maio de 1992, o seu primeiro programa de $d e b t$ for-nature swaps, numa transação que envolve a organização americana Nature Conservancy, a qual comprou, no mercado secundário da dívida, 2,2 milhões de dólares de títulos da dívida brasileira por 850 mil dólares, para os quais foram emitidos bônus do tesouro cujos juros estão estimados em 132 mil dólares ao ano, os quais serão doados a uma organização ambienta brasileira com vistas a financiar a promoção de um grande parque natural, o "Grande Sertão Veredas", com cerca de 211 mil acres de terra.

Outros projetos estão sendo estudados por uma Comissão Técnica de Avaliação de Projetos Ambientais (instituída pelo Decreto de 28.06.91), composta por representantes dos Ministérios da Economia e das Relações Exteriores, bem como das Secretarias de Tecnologia e Meio Ambiente.

Novos movimentos se delineam. O Bank of América anunciou, em 12 de abril de 1992, que doaria dois milhões de dólares em títulos da dívida externa brasileira a favor da Conservation International, cujos recursos seriam utilizados em programas de apoio à conservação dos sistemas ecológicos da Floresta Amazônica e do Pantanal do Mato Grosso. É do interesse deste Banco diminuir os seus compromissos financeiros no Brasil, que passaram de 2,1 bilhões de dólares, em 1988, para 486 milhões, em 1991.

Simultaneamente, o Governo japonês está disposto a financiar projetos de despoluição do Rio Tietê, da Baia de Guanabara, de projetos para a preservação de florestas em Minas Gerais, aproveitamento do lixo em São Paulo e Projeto "Pró-Vida" em Santa Catarina. Este financiamento atingiria a quantia de 800 milhões de dólares com condições de crédito concessionais. O Governo japonês poderia liberar estes recursos tão logo fosse firmado o acordo bilateral sobre as dívidas de governo a governo, no âmbito de acordo concluído entre o Brasil e o Clube de Paris, em fevereiro de 1992.

Todos estes últimos movimentos são acalentadores, no sentido de que as conversões ambientais terão seu espaço no cenário nacional, o que equivale a dizer que projetos ecológicos merecem das autoridades e da população brasileiras a devida atenção, haja vista a urgência dos problemas ambientais críticos que o país enfrenta.

\section{Conclusão}

O meio ambiente é, sem dúvida, o maior desafio deste fim de século. No entanto, a tentativa de restabelecer o meio ambiente 
viável dentro de um esquema econômico ecologicamente sustentável não se fará sem uma profunda auto-crítica do nosso modo de vida, e sem o investimento de importantes recursos financeiros e humanos.

Pelos cálculos do Secretariado da ECO92 serão necessários investimentos da ordem de 125 bilhões de dólares por ano, até o fim deste século, para cumprir as metas da "Agenda 21".

A luta é de todos. Hoje, mais do que nunca, a expressão "interdependência" é uma noção chave do Direito Internacional Geral e do Direito do Meio Ambiente, em particular.

O meio ambiente é de fato um patrimônio comum da humanidade, ainda que os recursos naturais se encontrem dentro dos limites das fronteiras nacionais.

Os países do Terceiro Mundo devem promover políticas ambientais lato sensu que incorporem aspectos demográficos, industriais e agrícolas. Entretanto, devemos ter presente que os principais responsáveis pela degradação ecológica do nosso planeta são os países industrializados. Estes, por sua vez, devem entender que é imprescindível uma severa disciplina sobre as suas indústrias poluidoras e que será essencial prover os países do Terceiro Mundo de recursos adicionais para financiar programas de reabilitação e proteção ambientais auto-sustentáveis.

Neste enfoque global não há divórcio entre a economia e o meio ambiente. A velha expressão "os poluidores serão os pagadores" revelou a sua ineficiência. Devemos repensar modos de consumo que deixem o planeta num estado viável para as futuras gerações.

Desde que aceitemos a idéia de que a luta para recompor a situação ambiental do planeta é de todos, e que recursos financeiros importantes serão indispensáveis a este fim, cabe interrogar-nos sobre a necessidade de definirmos uma novíssima ordem econômica internacional. A falecida "nova ordem internacional", integrada nas grandes Resoluções da Assembléia Geral das Nações Unidas nos anos 70, revelou a sua incapacidade 176 no sentido de resolver problemas de desenvolvimento, desde que a problemática foi apresentada sob um prisma confrontacional.

Passados vinte anos, os países desenvolvidos devem entender que os problemas de desenvolvimento, dentro dos quais o ambiental é de extraordinária importância, não são da única e exclusiva responsabilidade dos países do Terceiro Mundo. Aqueles, certamente, não têm interesse em manter às suas portas uma parte do mundo em desenvolvimento super povoada, super poluída, super endividada, que não poderá mais ser o parceiro econômico de que tanto precisam

A conversão da dívida externa em projetos ambientais é, portanto, um elemento revelador desta novíssima ordem econômica internacional, que se baseia numa responsabilidade comum e numa parceria econômica e humana da qual todos tiraremos proveito.

\section{Notas}

${ }^{1}$ Esta possibilidade também pode ser aberta à institujções oficiais, governamentais ou multilaterais, confor me veremos mais adiante.

$2 \mathrm{O}$ "mercado secundário da dívida" se desenvolveu nos anos de 1985-86, quando tornou-se claro que as dificuldades encontradas pelos paises devedores quanto ao pagamento de seus débitos externos iriam se prolongar. Muitos bancos, então, tentaram negociar os títulos que eles detinham, cuja credibilidade comercial havia sido comprometida. O "mercado secundário da dívida" revela o "verdadeiro" valor comercial desses títulos, constitui a aceitação explicita de que a divida do Terceiro Mundo não pode mais ser honrada segundo os termos contratuais inicialmente acordados.

${ }^{3}$ Os debt-for-equity swaps, ou conversão da dívida em projetos de investimento, são transaçōes nas quais um investidor estrangeiro adquire no mercado secundário os títulos da divida externa de um determinado pais com deságio, e os converte, junto ao Banco Central deste por moeda nacional com deságio de zero a trinta por cento, geralmente. Este capital, então, é investido mentesas nacionais existentes ou novas, tradicionalmente dentro de um programa de privatização. Se os principios basicos existentes entre os debt-forequity swaps e os debl-for-nature swaps sáo os mesmos, a grande diferença entre este dois tipos de conversōes é que, por
uma lado, no primeiro o país deverá abrir mão de parte de seu patrimônio industrial, aceitando remessas de lucros para o exterior e sofrendo uma grande pressão inflacionária, enquanto que nas conversōes ambientais os interesses da transação se reservam unicamente ao
pais devedor e the impõe uma pressão inflacionária pais devedor e lhe impõe uma pressão inflacionária praticamente
longo prazo.

${ }^{4}$ Um princípio costumeiro próprio das organizações internacionais financeiras se opõe a que sejam negocidos, de qualquer forma que seja, os empréstimos concedidos para projetos de desenvolvimento nos países devedores. Porém, a nova politica adotada em particu lar pelo Banco Mundial com o lançamento do Plano Brady de redução da divida, abre novas perspectivas para que esta instituição ofereça garantias visando constituição de novos instrumentos financeiros ligado constituição de novos instrumentos financeiros ligados
a projetos ambientais: foi proposto, em particular, a
criação de um Conservation Exit Bond no qual um criaçào de um Conservation Exit Bond no qual un Banco Central do país devedor com uma garantia a Banco Central do pais devedor com uma garantia a sessoria do

5 A conversão ambiental poderia entrar em conflito direto com várias cláusulas tradicionais de igual tratamento dos credores, incluídas nos contratos de reescalonamento (Sharing Clause, Mandatory Prepayment Cla se, Pari Passu Clause e Negative Pledge Clause), caso um credor recebesse um pagamento mesmo parcial do seus créditos na ausência de disposiçōes autorizand tal conversão no instrumento de renegociação da divida.

${ }^{6}$ A proposta do presidente Sevilla é de converter a dívida externa em bônus do Tesouro do país devedor, cujos interesses financiariam os projetos ambientais, $e$ quando do vencimento os bônus constituiriam um dotação em capital a favor da organização ambienta local. Esta solução apresenta inúmeras vantagens, comparada aos mecanismos que foram seguidos para as conversōes em que o Banco Central do pais devedor fornece de uma só vez o equivalente em moeda local do título da divida externa resgatado. De acordo com do thropsta Sevilla fica amenizado o problema dos a proposta Sevila, fica amenizado o p

7 O Fundo Operativo de 250.000 dólares aberto na Bolivia, fora constituído de duas contribuições. A contribuição boliviana foi financiada por uma programa norte-americano de assistência ao desenvolvimento: 0 "Public Law 480" autoriza o Governo dos Estados Unidos a adquirir e transferir excedentes agrícolas para paises 'em desenvolvimento se estes últimos fornecerem moeda nacional para projetos de desenvolvimento.

Tal procedimento foi utilizado na experiência boliviana.
8 Podemos ilustrar esta situação com um exemplo prático.

Supomos que a OING adquira um título da dívida externa de 100 dólares a $15 \%$ de seu valor de face $(15$ dólares); o Banco Central do país devedor converte destén $50 \%$ e uma taxa de câmbio de 1 dólar por 300 vintens, por exemplo. $O$ valor total os bônus emitidos de 15.000 vintens com um rendimento anual de $15 \%$, quando a taxa de inflação é de $100 \%$ ao ano. Por outro lado, os bônus não se beneficiam dos reajustes. Certamente, a OING preferirá, então, trocar os 15 dólares iniciais no mercado paralelo ( dólar $=800$ vintens), obtendo 12.000 vintens que serão doados diretamente à OLNG para projetos ambientais.

${ }^{9}$ Os maiores beneficiários da politica de subsídios e ajudas governamentais são as construtoras de auto-estradas e os fazendeiros, que sozinhos são os responsáveis por $60 \%$ da desflorestação. A suspensão das políticas de subsídios é por si só incapaz de prevenir recuperar os danos já causados.

10 Conforme art. 1 da Resolução 1.840 do Banco Central, reproduzida no BECEBE - Informativo Ecoômico e Financeiro, Vol. L II, 2 semestre, 1991, ps. 1.1 e 1.2 .

11 Esta Circular pode ser encontrada no BECEBE Informativo Econômico e Financeiro, Vol. L II, 2 semestre, 1991, ps. 2.11

\section{Bibliografia}

Barrans, David. "Promoting international environmental protections though foreing debt exchange transactions", in Cornell International Law Journal, Vol. 24, 1991, pp. 23-95.

Burand, Deborah. "Doing it naturally: the greening of international finance", in International Financial Law Review", Setembro, 1989, pp. 37-9.

Burton, Eve. "Debt for development: a new opportunity for nonprofits, commercial banks, and Developing States", in Harvard International Law Journal, Vol. 31, 1990, pp. 233-256.

Chamberlin, Michael e outros. "Sovereing debt exchanges", in University of illinois Law Review, Vol. 1988 , n.2. pp. $415-80$.

Conservation International. "The debt-for-nature exchan ge - A toll for international conservation", Washington D.C., setembro, 1989.

Gibson, J. Eugene e outro. "A debt-for-nature blueprint", in Columbia Journal os Transnational Law. Vol. 28, 1990, pp. 331-412.

Heynik, Tamara J. "Debt-for-nature swaps: effective but enforceable", in Case Western Reserve Journal of International Laze, Vol. 22, 1990, pp. 141-63.

Levin, Julia. "A comparison of forestry lares in the United States and Brazil as they promote deforestation in Soutbeastern Alaska and the Amazon Basin", in Hastinge International Comparative Law Review, Vol. 14, n.4, Symposium Issue, 1991, pp. 1017-40.

Von Moltke, Konrad. "Debt-for-nature; the second generation", in Hastings International and Comparative Law Reviewe, Vol. 14, n.4, Symposium Issue, 1991. 